\title{
UTJECAJ MEDIJSKOG NASILJA NA ADOLESCENTE I OBITELJ
}

\author{
Rozana Petani \\ Mirela Tolic \\ Sveučilište u Zadru, Odjel za pedagogiju \\ University of Zadar, Department of pedagogy \\ UDK: 316.77-053.6:37 \\ Pregledni članak / Review \\ Primljeno / Received: 6. XI. 2008.
}

\begin{abstract}
U radu se polazi od aktualnih problema post-modernog društva koje je obilježeno informacijskom tehnologijom i komunikacijom. Značajno je da putem medija, posebice elektronskih (internet, blogging, video igrice) komunikacija postaje poveznicom svijeta brzih promjena i inovacija. Upravo takav svijet današnjice, dakle svijet novih potreba mladih za informiranjem, za inovacijama i komunikacijom te novom vrstom zabave ima dvostruku ulogu. $S$ jedne strane, beznačajno pretvara u značajno, odnosno nepoznato u poznato, što omogućava uspješnu efektivnost u obrazovanju, dok s druge strane promovira nasilje. To je dovoljan razlog da se istakne značenje medijske i obiteljske pedagogije u empirijskim analizama fenomena nasilja i edukaciji mladih i njihovih roditelja.

Danas su mediji dio obiteljskog ozračja te svojim postojanjem i porukama djeluju na obitelj i njezine članove, ali o upotrebi medija i njihovim pozitivnim ili negativnim učincima odgovorno odlučuju sami članovi obitelji. Može se reći da su roditelji neizbježan medijski socijalizator i jedan od presudnih čimbenika koji omogućuje djeci i mladima razlikovati fikciju od stvarnosti te pozitivne od negativnih sadržaja.

Pod pojmom medijskog nasilja podrazumijeva se: indoktrinacija, laž, diskriminacija, uvrede, ucijene i rasna segregacija djece i mladih. Navodi se da su mediji (TV, filmovi, internet, blogging, video igrice) potencijalno moćni manipulatori koji vode samo kratkoročnoj ugodi, a zapravo prevladava dugoročno gubljenje osobnosti. Mogućnost rješavanja problema po pitanju nasilja u medijima vidi se u medijskoj i obiteljskoj pedagogiji.
\end{abstract}

KLJUČNE RIJEČI: adolescenti, mediji, medijska i obiteljska pedagogija, nasilje, uloga obitelji

NASilje U MEdijima - NASILJE U REALNOSTI

Posljednjih godina postoji puno radova koji se bave istraživanjem koliko nasilje u medijima doprinosi razvoju agresije i nasilničkog ponašanja mladih (Bushman i Huesmann, 2001; Ilišin i sur., 2001, 2003; Buchanan i sur., 2002; Anderson i sur., 2003; Huesmann i sur. 2003; Miliša i Zloković 2008). Namjera nam je potaknuti važne aspekte analize medijskog nasilja i istaknuti da ova problematika zahtjeva širi, multidisciplinarni pristup. Glavnina istraživanja je pokazala da djeca i mladi koji su izloženi agresivnim i nasilnim sadržajima u medijima pokazuju agresivnije ponašanje i stavove. Nasilje potiču sljedeći razlozi: nepostojanje verbalne komunikacije, nedostatak stručnjaka u školama i 
preventivnih programa (najveći nedostatak stručnjaka pedagoško-psihološke službe je u područjima od posebne državne skrbi), zatim odgojna atrofija škole, vrijednosna matrica da cilj opravdava sva sredstva, nasilje kao reakcija na dezorganiziranost društva i probleme mladih, sve izraženija depresija i neurotičnost adolescenata itd. (Mrkonjić, Miliša, 2005). $\mathrm{Na}$ taj način mladi postaju prognanici života i/ili se nalaze na rubu društva.

Nasilje u medijima od svjesnog pojedinca može učiniti pasivnog konzumenta ili promatrača koji smatra kako su sve deformacije normalne, a upravo u tome i jest razorna moć medija-manipulatora. Mediji poput interneta, TV i sl. potencijalno su moćni manipulatori jer utječu na mladog čovjeka da sa sumnjom i nevjericom gleda na sveukupnu javnost. Glavni alibi ovakvih medija jest privući i fascinirati korisnika, te kratkoročno stvoriti trenutnu ugodu i zadovoljstvo, a dugoročno dovodi do gubljenja osobnosti. Smatramo da medijsko nasilje, poput onog na internetu, TV-u, u filmovima i sl., direktno utječe na razvoj agresivnog ponašanja kod mladih. Theunert (2006) pod pojmom medijskog nasilja podrazumijeva indoktrinaciju, laž, diskriminaciju, uvrede, ucjene i rasnu segregaciju djece te naglašava karakter moći koji se odnosi na autoritarnost, koju izjednačava s manipulacijom. Prema istom autoru "moć je glavno sredstvo manipulacije" (Theunert, 2006: 63-64), što se može slikovito prikazati na sljedeći način (vidi sliku 1.).

Neka su istraživanja pokazala da se kod mladih izloženih agresiji i nasilju putem medija javljaju različite psihičke posljedice (Bandura, 1959, 1961; Anderson i Bushman, 2001; Bushman i Huesmann 2001): realnost zamijenjena iluzijom, gubljenje i kriza identiteta, manja osjetljivost na nasilje i za one koji pate od nasilja, povećanje asocijalnog i agresivnog ponašanja, viđenje nasilja kao prihvatljiva u rješavanju konflikata itd. Potrebno je još istaknuti kako nasilje u medijima više utječe na djecu koja su mlađe dobi jer ih je lakše impresionirati, teže im je razlikovati fikciju od realnosti, jer ne mogu razlučiti motive za nasiljem i uče upravo promatranjem i imitacijom.

Istraživanje Kaiser Family Foundation (2005) pokazalo je da djeca od 8 do 18 godina provedu više vremena ispred kompjutera, televizije i u videoigricama (44,5 sati tjedno), nego u bilo kojim drugim aktivnostima.

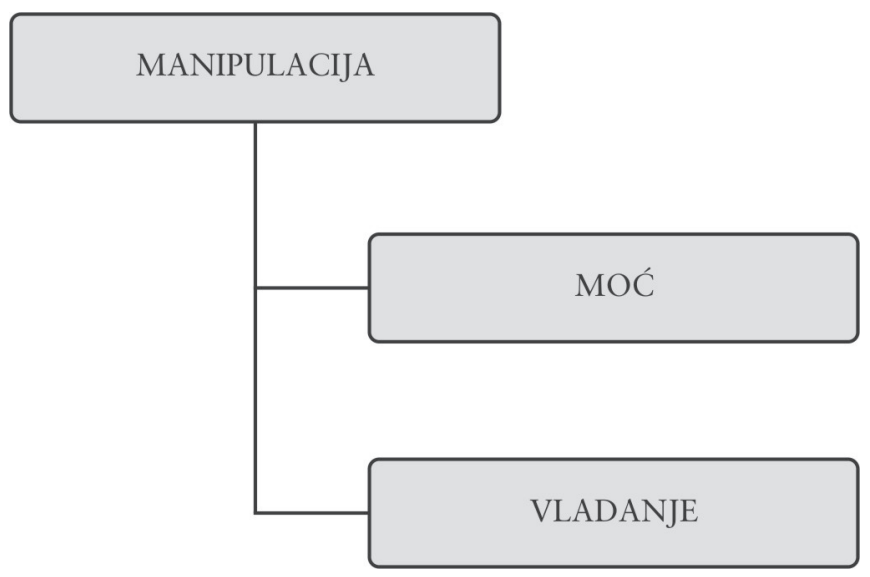

Slika 1. Moć i vladanje kao sredstvo manipulacije (prema Theunert, 2006) 
Djeca i mladi koji više gledaju TV i igraju videoigrice nisu samo više izloženi medijskom nasilju već su agresivnija među svojim vršnjacima i imaju izrazitu tendenciju da više takva ponašanja poprimaju u svojim interakcijama s drugima (Buchanan i sur., 2002).

Nadalje, istraživanja pokazuju da korištenje interneta kod adolescenata eksponencijalno raste u posljednjem desetljeću, a taj rast prate: 1) razlike po spolu, npr. dječaci provode više vremena online, surfajući na webu i igrajući nasilne igrice, dok djevojke više koriste chat ili online kupovinu; 2) korištenje interneta uzrokuje socijalnu izolaciju i depresiju, osobito kod adolescenata; i 3) adolescenti koriste internet za anonimno eksperimentiranje svojim identitetom (Gross, 2004).

Istraživanja Njemačkog instituta ${ }^{1}$ u Mainzu (2007) pokazala su da su mladi koji su bili u grupi s kojom se detaljno radilo o pitanjima informiranja, o fenomenu nasilja $u$ medijima i izvan njih svjesniji mogućnosti medijske manipulacije od grupe mladih koji nisu sudjelovali u informiranju o negativnim efektima medija. Istraživanje je također pokazalo da mladi iznad 16 godina na internetu najčešće posjećuju blogove. Sadržaji na koje su nailazili na blogovima, a koje navode ispitanici, u većini su slučajeva nasilje i pornografija, zatim slijede zabava, način korištenja slobodnog vremena a na posljednjem su mjestu nove informacije. $U$ istom istraživanju na postavljeno pitanje koliko vremena dnevno provode na blogovima, ispitanici su odgovorili sljedeće: 1 sat dnevno 48,9\%; 2 sata dnevno 41,0\%; 2-4 sata dnevno $8,0 \%$; 4 sata dnevno $2,1 \%$ ispitanika. Na pitanje kako ocjenjuju blogove, odgovorili su: zanimljivo $92,5 \%$; indiferentno $6,1 \%$; beskorisno $0,3 \%$; opasno $1,1 \%$.

Nakon pregleda iznesenih rezultata istraživanja uočljivo je da je medijsko nasilje postalo jedan od najvećih problema današnjeg društva, no treba istaknuti da to ne znači kako mediji generiraju nasilje, nego treba reći da nasilje koje u društvu već postoji, mediji izrabljuju te oblikuju na svoj način radi bolje zarade i manipulacije nad pojedincem. U nastavku navodimo nekoliko primjera agresivna ponašanja mladih koji se mogu naći u dnevnom tisku i internetskim stranicama:

- Motiv masakra u SAD-u (prosinac 2007.) koji je počinio devetnaestogodišnjak te pri tome nasumice ubio devet i ranio pet osoba, naknadno je otkriven u tisku, jer je prije nego što je sebi oduzeo život, napisao poruku: "Sada ću biti slavan!" (www.//jugendgewalt.de).

- Bejzbolske palice su postale simbol bandi (www.//jugendgewalt.de), a o isto izvješćuju i splitski novinari - "Brđani" i "Getani" ratuju bejzbolskim palicama.

- Šokantni su i pronađeni grafiti: u Rijeci "Kriminal je smisao naše mudrosti"; u Osijeku "Gdje je krvi tu si prvi"; u Zadru "Najbolji oblik samokritike je samoubojstvo"; u Puli "Ako škola znači život, živjela smrt". To su po(r)uke koje se potiču u senzacionalističkom tisku, nasilnim scenama, video-igricama, elektroničkim medijima itd.

Nasilje, smrt, pornografski materijali, pedofilija, kriminal itd. stvaraju socijalno izolirana pojedinca. Nasilje postaje stilom života, a mladi koji imaju nizak stupanj samopoštovanja skloniji su krizi identiteta i većem utjecaju nasilja. Tako mladi kroz sukobe traže sebe, jer nasilje nad mladima inicira i nasilje među mladima.

\footnotetext{
${ }^{1}$ Institut für Medienpädagogik in Mainz - Johannes

Guttenberg Universität, 2007 (interni podaci)
} 


\section{Dvostruka uloga medija i MEdijska PEDAgogija}

Pozitivna uloga medija ima strukturalno i simboličko značenje. Kroz strukturalno značenje djelovanje medija odnosi se na mjesto pojedinaca u društvu. Oni su prijenosnici simbola od čovjeka k čovjeku. Mediji se razvrstavaju u tri grupe: primarne (neopipljivi, npr. jezik), sekundarne (odnosi se na produkciju medijskih sadržaja, npr. glazba) i tercijarne (kombinacija prethodnih) (Schrob, 1995: 45).

Hug (2007: 87) je došao do zaključka da postoji šest funkcija medija u tehničkim komunikacijama, tj. digitalnim medijima:

1. organizacija razmjene komunikacije

2. razumljivost informacija

3. socijalna organizacija društva

4. kulturalna reprodukcija

5. transfer komunikacije među pojedincima i

6. demokratizacija obrazovanja i interkulturalna funkcija.

Svjedoci smo da mladi danas sve više postaju robovi i ovisnici o blogovima, internetu, videoigricama kao sredstvima masovnih komunikacija. Međutim uz to je prisutna i socijalna potištenost, izoliranost te nasilje, što znači da se mladima otvaraju novi putovi pristupa informacijama i formiranja identiteta, a to sa sobom donosi poteškoće i opasnosti za osobni razvoj.

Temeljno pitanje koje se javlja jest otkrivanje dvostruke uloge medija koji utječu na identitet mladih, vrijednosti i njihovo ponašanje. Tehnološki napredak otvara izvanrednu mogućnost raznovrsnih pristupa informacijama, ali ne treba zaboraviti i onu drugu stranu "medalje", naime da informacije imaju manipulativne efekte te da promoviraju nasilje među mladima. Zbog toga je uporaba medija, pored informativno-obrazovne uloge često i u funkciji indoktrinacije i/ili manipulacije (Miliša, 2006). "Elektronički mediji (s određenim sadržajima i/ili emisijama) poprimaju najsofisticiraniji oblik manipuliranja nad mladima i vode (ne)izravno u ovisnosti o različitim (s)tvarima jer afirmiraju oslobađanje od rada u dokoličarenju ${ }^{2}$ i nestajanja svakog vida (samo)odgovornosti. Kroz zabavu manipulator plasira komercijalizaciju života i svih vrijednosti" (Miliša, 2008: 57). Uspjeh je zajamčen formom: seks, senzacija i skandali. Choen je u svojoj studiji kazao da će pitanje kako je određeni (devijantni) događaj prikazan u medijima, kod najvećeg dijela ljudi "stvoriti predstavu o tom događaju ili devijantnosti" (Choen, 1980: 30). Isti autor je još sedamdesetih godina upozoravao da mediji pored informativnih sadržaja sve više znaju manipulirati sadržajima s preuveličavanjem događaja ili iskrivljavanjem činjenica.

${ }^{2}$ Dokoličarenje danas sve više postaje način zabave,
ali kroz svojevrsni bijeg od organiziranog rada u
kojemu pojedinac sve manje sam participira ili
samostalno odlučuje o njegovu korištenju. Ono
se je "otrgnulo" ranijem poimanju kreativnog
izražavanja u slobodnom vremenu. Dokoličarenje
sve više postaje prepoznatljiv potrošački stil ponašanja, posebno mladih i uglavnom podrazumijeva pasivni odnos prema ponuđenim sadržajima. Nije li jedan od problema mladih o kojemu se puno govori, a malo piše i istražuje višak dosade i manjak ambicija i koje su posljedice toga!? (Miliša, 2006) 
Svjesni smo da je danas nemoguće razmatrati bilo kakve aspekte života mladih izvan konteksta utjecaja medija, ali kakve će učinke mediji ostvarivati, ovisi upravo o tome kako će oni biti upotrijebljeni (Ilišin, 2001). Iz toga proizlazi da: što je jača svijest o medijskom djelovanju, to je manja šansa za njegovo negativno djelovanje.

Kako ojačati svijest mladih o medijskom djelovanju i spriječiti medijsko manipuliranje? $\mathrm{Na}$ ovo pitanje odgovor može dati medijska pedagogija. Medijska pedagogija je mlada disciplina koja sadrži sva sociopedagoška, sociopolitička i sociokulturna razmišljanja o ponudama medija za djecu, mlade i ljudi treće dobi te analizira njihove interese koji se javljaju u odrastanju, radu, u slobodnom vremenu i obiteljskom životu. Razvoj medijskog obrazovanja pospješuje razvoj medijske kompetencije - kritičkog stava prema svim vrstama inovativnih medija, posebice blogginga, koji je postao trend među mladima. Cilj medijske pedagogije jest razumjeti dvostruku funkciju inovativnih medija i naučiti se njima pravilno služiti (Baacke, 2007). Potrebno je mijenjati medije na taj način da doprinose stvaranju identiteta mladih i da imaju odgojnu ulogu, a ne manipulativnu. Medijska pedagogija treba na pravi način ponuditi korištenje interneta, blogova i drugih medija kako bi se doprinijelo razvoju tog procesa. Ona bi mogla ponuditi nove koncepte i razviti metode kako bi se (posebice) mladi znali koristiti medijima koji imaju socijalnu i integracijsku dimenziju. Medijsku pedagogiju može se razmatrati kroz dva aspekta u užem i širem značenju (Schrob, 1995: 27):

\begin{tabular}{|c|c|}
\hline Medijska pedagogija u užem značenju & Medijska pedagogija u širem značenju \\
\hline $\begin{array}{ll}\text { - } & \text { primarni pristupi pedagogijskim } \\
& \text { zahtjevima } \\
\text { - } & \text { koncentracija na pedagoške odnose } \\
& \text { u interkulturalnim i nastavničkim } \\
& \text { dimenzijama } \\
\text { - } & \text { koncentracija na djecu i mlade } \\
\text { - } & \text { teorija i praksa odgoja } \\
\text { - } & \text { konceptualizacija antropološke } \\
& \text { dimenzije u odgoju } \\
\text { - } & \text { demokratičnost nastavnog procesa } \\
\text { - } & \text { kulturalno- pedagoške perspektive }\end{array}$ & $\begin{array}{ll}\text { - } & \text { teorijsko-komparativni pristupi } \\
\text { - } & \text { masovna komunikacija, političke i } \\
\text { društvene dimenzije } \\
\text { - } & \text { pedagogija kao "dadilja" kroz život } \\
\text { - } & \text { favoriziranje interdisciplinarnih } \\
& \text { pristupa } \\
\text { - } & \text { antropološki koncepti i njihove } \\
& \text { značajne funkcije } \\
\text { - } & \text { interpretacija antropološke koncepcije } \\
& \text { sa sociokulturnog aspekta } \\
\text { - } & \text { transfer informacija i demokratizacija } \\
& \text { obrazovanja } \\
\text { - } & \text { globalne i interkulturalne perspektive }\end{array}$ \\
\hline
\end{tabular}

(Izvor: Schrob, 1995: 27).

Njene poddiscipline poput medijske didaktike i medijskog obrazovanja imaju u tome vodeću ulogu. Takav način korištenja medija sprječava manipulaciju putem inovativnih medija koja prerasta u nasilje (Miliša, 2006). Na shematskom prikazu možemo vidjeti koji mediji najeksplicitnije manipuliraju: 


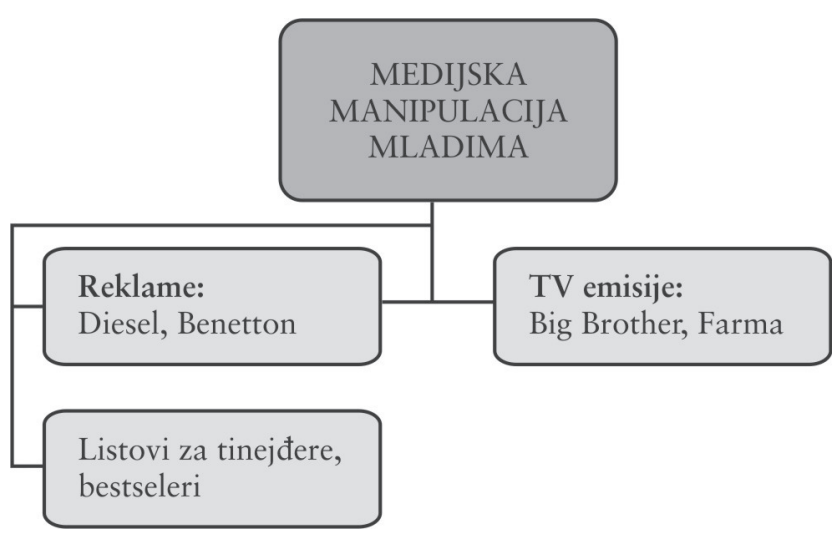

Slika 2. Način manipulacije mladima

Za prevenciju medijskog manipuliranja koja vodi $\mathrm{k}$ medijskom nasilju od velikog je značenja stjecanje medijskih kompetencija i obiteljska komunikacija, gdje obitelj kao zajednica ima vodeću ulogu u tom procesu. Baacke (2007) je prvi uveo pojam komunikativne kompetencije u odgojnim znanostima kao ono što prethodi medijskoj kompetenciji. Pod pojmom komunikativne kompetencije podrazumijeva se cjelokupna sposobnost čovjeka da razumije, sporazumi se i izmjenjuje jezične simbole (Schrob, 1995, prema Baacke, 2007: 27). Prema istom autoru medijsku kompetenciju uvjetuju:
a) individualna i demokratska orijentacija primatelja
b) dekodiranje medijskih simbola
c) aktivno korištenje medija: informacijska funkcija
d) kritička refleksija
e) razvitak kritičkog medijskog okruženja
f) emancipiranost i motiviranost medijskog korisnika
g) svjesnost pojedinca.

Baacke (2007) ih je operacionalizirao u sljedeće dimenzije: medijska kritika (sposobnost analize sadržaja medija), medijsko znanje (znanje o medijima i sistemima, te sposobnost produkcije), medijsko korištenje (receptivna komponenta korištenje medija, npr. interaktivno korištenje kako i na koji način, te s kojim posljedicama) i medijske forme djelovanja (inovativni medijski sistemi, kreativnost i estetske forme). Dva temeljna glagola kao osnova za izgradnju pojedinačne medijske kompetencije: znati-znanje i moćidjelovanje (Baacke, 2007: 67). 


\section{Adolescenti i MEdiji}

S obzirom na to da se u radu govori o mladima, adolescentima, a oni su osobito osjetljiva populacija, potrebno je prije svega definirati pojam adolescencije. Adolescenciju možemo definirati kao period tranzicije od djetinjstva do zrelosti s univerzalnim morfološkim, psihološkim i kognitivnim promjenama. Karakterizira je ubrzani proces promjena u socijalnom i psihološkom funkcioniranju, kao i fizički rast (McNamara, 2000). Unatoč zajedničkim karakteristikama, postoje velike individualne razlike u periodu razvoja kroz adolescenciju, koje pokazuju utjecaji socijalnih i ekonomskih čimbenika. Prema nekim autorima opseg ovih razlika i način njihova manifestiranja rezultat su "socijalne ekologije" koja uključuje obiteljsko okruženje, komunikaciju, socijalnu strukturu, geografsko i političko područje, kulturalni i povijesni kontekst (McNamara, 2000; Lacković-Grgin, 2006). Prema Eriksonu (1980) čovjek u svom razvoju prolazi kroz osam stadija. Svaki je od njih obilježen krizom koju je potrebno riješiti kako bi osoba mogla dalje napredovati. Period adolescencije započinje u petom stadiju, kojemu je Erikson posvetio posebnu pažnju. Glavni zadatak tog stadija jest izgradnja identiteta, koja započinje u djetinjstvu, a $\mathrm{u}$ adolescenciji je to ključna psihosocijalna tema. S obzirom na to da kod adolescenata tada imamo izražen tjelesni odnosno seksualni razvoj te razvoj identiteta, mladi ljudi moraju integrirati sve elemente identiteta, tj. moraju riješiti krizu identiteta. Tu je vrlo važan odgoj u obitelji, školi te neformalni vidovi odgoja i kvalitetna komunikacija. Adolescenti su tada svjesni svojih obilježja, svojih želja i ciljeva, ali isto tako pred njima se nalaze i zahtjevi društva kao što su završetak školovanja, uključivanje u svijet rada, pronalaženje partnera, odabir političke filozofije i religijskog uvjerenja. Zahtjevi društva ne moraju uvijek biti u skladu sa zahtjevima adolescenata pa se zbog toga oni susreću i s problemima redefiniranja identiteta.

Danas mladi žive u postmoderno doba, u vremenu u kojemu su sve veće mogućnosti kreiranja čovjekovih sloboda, ali to je i vrijeme porobljavanja mladog čovjeka, vrijeme u kojemu se gubi identitet, kritičnost, intrinzične vrijednosti, potrebe i (samo)poštovanje. Može se reći da je pred naletom suvremene tehnologije nastao socijalno izolirani pojedinac. Mladi, doduše, danas imaju veću mogućnost izbora, ali ih prati slabi utjecaj socijalnih vrjednota te nesnalažljivost u ubrzanu razvoju tehničke revolucije. Mladima s jedne strane problem predstavlja što se moraju integrirati u takvo društvo, dok im se s druge strane otvaraju bogatije mogućnosti informiranja, korištenja tehnoloških komunikacija, mobilnost i sl. Smatramo da mladi nisu spremni pratiti naglu brzinu razvoja tehnološkog društva. Oni su često izmanipulirani od strane moćnika, odnosno medija (TV, filmovi, internet, video-igrice) koji predstavljaju marketinški instrument tzv. online-marketing. U procesu digitalizacije primjećuje se slabljenje tradicionalnih vrejdnota što utječe na razvoj identiteta mladih, a znamo da identitet mladog čovjeka ne predstavlja samo izraz onoga što on jest, već i onoga što želi biti.

Veliki broj istraživanja pokazuju da značajan dio agresivne djece razvije agresivno ponašanje i u odrasloj dobi te da su vrlo agresivni adolescenti pokazivali agresivnost i nasilno ponašanje i u mlađoj dobi. A to pak znači da je jedan od značajnih prediktora nasilna ponašanja starijih adolescenata agresivno ponašanje u mlađoj dobi (Huesmann i Moise, 1998, prema Anderson i sur., 2003; Tremblay, 2000). 


\section{ULOGA OBITELJI I MEDIJI}

Obitelj je mjesto gdje dijete stječe svoja prva životna iskustva, znanja i vještine. Tu se stvara i razvija vlastiti identitet. Ne postoji nikakva druga zajednica koja bi mogla biti supstitut za obitelj. U odnosima s roditeljima djeca stječu osjećaj sigurnosti ili nesigurnosti, iskrenosti, povjerenja i razumijevanja, razvijaju osjećaj pripadnosti ili nerazumijevanja i izoliranosti od drugih članova obitelji. Suvremena obitelj suočena je s mnogim svakodnevnim pritiscima i problemima, zbog kojih članovi obitelji mogu imati osjećaj usamljenosti, otuđenosti i slabe emocionalne povezanosti. U nekim obiteljima emocionalni i neposredni kontakt vrlo je rijedak i zamijenjen tzv. virtualnim odnosom (komuniciranje telefonom, sms porukama, e-mail, gledanje TV-a), a osjećaj topline, razumijevanja i međusobne podrške gotovo su marginalizirani.

Suvremena istraživanja pokazuju veliku prisutnost svih vrsta medija u obiteljima današnjice: TV, radio, mobiteli, novine, kompjuteri i internet. Istraživanje koje proveo GfK-Centar za istraživanje tržišta (Centre for Market Research) ${ }^{3}$ iz Zagreba (2005) pokazalo je da u Hrvatskoj 48\% kućanstava posjeduje kompjuter, 7\% laptop a 35\% ih je priključeno na internet.

Kad govorimo o utjecaju medija na djecu i mlade, nužno se postavlja pitanje o ulozi roditelja i obitelji. Roditelji su neizbježan medijski socijalizator, a roditeljska intervencija osobito je važna kod mlađe djece, koja se tek upoznaju s medijskom ponudom.

Singer (1986, prema Anderson, 2003) je utvrdio: kad roditelji preuzmu aktivnu ulogu posrednika između djece i medija tako što redovno razgovaraju s djecom o ponuđenim sadržajima, zauzimaju kritičan i realan stav prema njima te procjenjuju sadržaje i tome uče djecu - tada je manja vjerojatnost lošeg utjecaja medija na dijete.

Istraživanje koje je proveo Nathanson (1999) pokazalo je da djeca roditelja koji s njima diskutiraju o neprimjernim nasilnim televizijskim sadržajima i koji djeci ograničavaju pristup takvim sadržajima, pokazuju manje agresivnih tendencija nego djeca koja imaju roditelje s kojima ne razgovaraju i koji im ne ograničavaju izloženost i pristup takvim sadržajima.

Istraživanja provedena kod nas (Ilišin, 2003, Trstenjak, 2006, Miliša, 2007, 2008) su pokazala da je s djecom potrebno razgovarati o svemu što su vidjeli i čuli, s namjerom da im se pomogne vrjednovati značenje te da shvate moralnu pouku i prirodu sadržaja koji im se nudi, to prije što samo $10-15 \%$ djece razgovara s roditeljima o tome što su gledali, slušali ili pročitali (Košir, 1999).

Nekoliko istraživanja, koja su ispitivala karakteristike roditelja kao moguće moderatore dječjeg ponašanja, utvrdila su malo dokaza koji govore da čimbenici kao što su roditeljska agresivnost, hladnoća, osobnost ili navika gledanja TV-a pojačavaju ili smanjuju efekte izloženosti nasilju (Huesmann i sur. 2003). A to znači da način na koji roditelji kontroliraju izloženost djeteta medijima te kako se ponašaju i što rade kada dijete vidi nasilje, više utječe na dijete nego ono što zapravo roditelj jest.

Rezultati istraživanja također pokazuju da je velik broj djece ne samo u obitelji već i u školi izloženo omalovažavanju, vrijeđanju, ponižavanju i sličnim ponašanjima, što također

\footnotetext{
${ }^{3}$ Vidi: http://www.gfk.hr/default.htm
} 
utječe na krizu odgoja (Bilić i Zloković, 2004). U istom istraživanju pokazalo se da jedna četvrtina mladih doživljava (vlastitu) obitelj kao "opasnu sredinu".

Zadatak stručnjaka i profesionalaca jest da pomognu i educiraju roditelje da razgovaraju sa svojom djecom, da im pomognu razlikovati fikciju od stvarnosti, da ih uče selektivno odabirati sadržaje te prepoznavati pozitivne i negativne značajke medija. Vrlo je važno s djecom razgovarati o tome što je nasilje, pa kad jednom nauče što je nasilje, djeca mogu i medijsko nasilje staviti u kontekst u kojem se događa. Također je potrebno istaknuti kako se nasilje koristi u različitim medijima, npr.koristi li se nasilje nepotrebno ili je dio plana; koristi li se na humorističan način te je zbog toga manje štetno; prikazuje li se nasilje kao jedini način rješenja problema i sl. Roditelji trebaju s djecom razgovarati i o posljedicama medijskog nasilja, dakle o tome kako bi se likovi koji su izloženi nasilju osjećali u realnom životu, kako bi počinitelje nasilja trebalo kazniti. Sljedeće o čemu se s djecom i mladima može razgovarati jest i pitanje zašto je nasilje u medijima privlačno ljudima i osjećaju li se oni kao mete onih koji u medijima prodaju nasilje. Potrebno je zajedno s djecom potražiti kreativne načine za rješavanje konflikata u medijima i o tome s njima raspravljati, potražiti koji su stereotipi vezani za nasilje u medijima (tko su počinitelji, a tko žrtve - muškarci, žene, stariji ljudi, djeca, bijelci, manjine itd.). Kao posljednje, ali ne manje važno, treba razgovarati s djecom o nasilju u informativnim emisijama, dakle o tome da se ratovi i terorizam stave u povijesni i kulturni kontekst te da se raspravlja o nasilju i kriminalu što se događa u društvu kako djeca time ne bi bila zaplašena.

Zajedno sa svim članovima obitelji roditelji bi trebali biti prvi u aktivnom dijaloškom odnosu, odlučivati o vremenskom prostoru za medije, ulaziti u svijet svoje djece i poznavati njihove ukuse, učiti ih da budu kritični i znati im predložiti alternative, jer pravi medij nije ni internet, ni blog, ni TV, nego obitelj. Obitelj ima slobodu i odgovornost u upravljanju medijima na vlastiti način (Trstenjak, 2006).

\section{ZAKLJUČAK}

Mladi su populacija koja je vrlo podložna različitim vrstama utjecaja. Jedan od njih su i utjecaji koji im dolaze putem medija (internet, TV, filmovi, videoigrice). Snaga i doprinos medija jest u dostupnosti i širenju novih znanja, u stimuliranju i olakšavanju učenja, u promicanju ljudskih prava, upoznavanju različitih kultura i nacija, u bržem protoku informacija i sl. Međutim postoji i negativna strana medija koja se očituje u manipulaciji mladima i promoviranju nasilja i agresivnosti. Mediji predstavljaju marketinški instrument tzv. "online-marketing". Istraživanja su pokazala da se kod mladih što su izloženi agresiji i nasilju u medijima, javljaju različite psihičke posljedice, a sve su postale jedan od većih problema današnjeg društva. Kakve će učinke nasilje u medijima ostaviti na mlade, ovisi o tome na koji će način ti mediji biti upotrijebljeni. Mediji koji manipuliraju, zalažu se tobože za liberalne svjetonazore, a putem reklama nude viziju da svi živimo isti život, dijelimo iste vrijednosti, a da su naše pojedinačne osobne kvalitete netragom nestale.

Zbog toga je vrlo važno ojačati svijest o medijskom djelovanju na mlade, jer je tada manja mogućnost njegova negativnog djelovanja. Ključnu ulogu u tome ima obitelj i roditelji. Suvremena su istraživanja pokazala veliku prisutnost svih vrsta medija u obiteljima današnjice. I može se reći da su roditelji dobili velikog suparnika u odgajanju svoje djece, a to je televizija koja sve više privlači njihovu pozornost i u kojoj su djeca pronašla lukavog 
saveznika u bijegu od svijeta svojih roditelja (Buchanan, 2003). Roditelji su neizbježan medijski socijalizator, a zadatak stručnjaka i profesionalaca je da im pomognu i da ih educiraju kako bi što bolje i odgovornije obavljali svoju roditeljsku ulogu i pomogli svojoj djeci da razumiju poruke koje dolaze iz svih medija, da ih kritički prihvaćaju i propituju značenje ponuda što im se nude.

\section{LITERATURA}

Anderson, C. A. i Bushman, B. J. (2001) Effect of violent video games on aggressive behavior, aggressive cognition, aggressive affect, psysiological arousal, and prosocial behavior: A meta-analytic review of the scientific literature, Psychological Science, 12, 353.

Anderson, C. A., Berkowitz, L., Donnerstein, L., Huesmann, L. R., Johnsin, J. D., Linz, D., Malamuth, N. M. i Wartella, E. (2003) The Influence of media violence on youth, Psychological Science in the Public Interest, Vol.4, No. 3/2003, str. 81-110.

Baacke, D. (2007) Medienpadagogik, Tübingen, Max Niemeyer Verlag.

Bandura, A. i Walters, R. H. (1959) Adolescent aggression, New York, Ronald.

Bandura, A., Ross, D. i Ross, Sh. A. (1961) Transmission of Aggression trough Imitation of Aggressive Models, Journal of Abnormal and Social Psychology, 63, str. 577-582.

Bilić, V. i Zloković, J. (2004) Fenomen maltretiranja djece, Zagreb, Ljevak.

Buchanan, A. M., Gentile, D. A., Nelson, D. A., Walsh, D .A. i Hensel, J. (2002) What goes in must come out: Childrens media violence consumption at home and aggressive behaviors at school. Paper presented at the International Society for the Study of Behavioural Develompent Conference, Ottawa, Ontario, Canada.

URL: www.mediafamily.org/research/report_issbd_2002.shtml

Buchanan, J. P. (2003) Smrt Zapada, Zagreb, Kapitol.

Bushman, B. J. i Huesmann, L. R. (2001) Effects of televised violence on aggression. In D.G. Singer i J. L. Singer (Eds.), Handbook of children and the media (Ch. 11, pp.223254), Thousand Oaks, CA: Sage.

Choen, S. (1980) Folk Delvis and Moral Panicss, London, Oxford- Martin Robertson, European Monetary System. University of Illinois EUC Working Paper, Vol.1, No. 1.

Erikson, E. (1980) Identity and life cycle, New York, Norton.

Gross, E. F. (2004) Adolescent Internet use: What we expect, what teens report, Applied Developmental Psychology, 25/2004, str 633-649.

Huesmann, R. L., Moise-Titus, J., Podolski, Ch. i Eron, L. D. (2003) Longitudinal Relations Between Children's Exposure to TV Violence and Their Aggressive and Violent Behavior in Young Adulthood: 1977-1992, Developmental Psychology, Vol.39, No. 2, str. 201-221. 
Hug, T. (2007) Aufwachsen im Medienzeitalter - Uberlegungen zu den veranderten aufgabenbereichen und Zustandigkeit der Medienpadagogig, Institut fur Erzhienugswissenschaft der Uni Innstruck.

Ilišin, V., Marinović-Bobinac, A. i Radin, F. (2001) Djeca i mediji, Zagreb, IDIS.

Ilišin, V. (2003) Mediji u slobodnom vremenu djece i komunikacija o medijskim sadržajima, Medijska istraživanja, 9(2), str. 9-34.

Kaiser Family Foundation (2005) Generation M: Media in the lives of eight to eighteen year olds. URL: http://www.kff.org/entmedia/entmedia03905pkg.cfm

Košir, M., Zgrabljić, N. i Ranfl, R. (1999) Život s medijima - priručnik o odgoju za medije, Zagreb, Doron.

Lacković-Grgin, K. (2006) Psihologija adolescencije, Jastrebarsko, Naklada Slap.

McNamara, S. (2000) Stress and Young People: What's New and What Can We Do?, London/New York, Continuum.

Miliša, Z. (2006) Manipuliranje potrebama mladih, Zagreb, MarkoM.

Miliša, Z. i Zloković, J. (2008) Odgoj i manipulacija djecom u obiteljima i medijima, Zadar-Rijeka, MarkoM.

Mrkonjić, A. i Miliša, Z. (2005) Sociopedagoške teme, Rijeka, DigitalPoint.

Nathanson, A. I. (1999) Identifying and explaining the ralationship between parental mediation and children's aggression, Communication Research, 26, str. 124-143.

Schrob, B. (1995) Medienaltag und Handeln. Medienpadagogik in Geschichte, Forschung und Praxis, Opladen: Gmbh.

Theunert, H. (2006) Gewalt in den Medien - Gewalt in der Rälitat, München Verlag, KoPad.

Tremblay, R. E. (2000) The development of aggressive behavior during childhood: What have we learned in the past century? International Journal of Behavioral Development, 24 , str. 129-141.

Trstenjak, T. (2006) Masovni mediji - poticaj ili smetnja obiteljskom dijalogu, Obnovljeni život (61) 4, str. 479-488. 


\section{The Influence of Violence in the Media on Adolescents and the Family}

\section{SUMMARY}

The topic of this paper is deeply rooted in actual problems of postmodern society that is marked by unprecedented development of information and communication technology. Through new media especially internet, bloggs, video games etc. the communication that develops, links the world of the change and innovation. That world exactly, is the world where we witness the new needs of the young generation. That need although appears as something already seen: a need for information, innovation, communication pleasure, now has a double meaning. On one hand it turns unimportant to important, unknown to well known, that supports the educational process, but on the another hand it promotes violence. This allows us to point to the importance of the media education and family education.

In the here and now, the media which is one of the most important agents of socialization, influences family as a whole as well as its members. The parents should be supported to retain their role as educators.

Keeping in mind that media violence is seen through indoctrination, lie, discrimination, insults and racial and gender segregation, that the youngsters encounter daily; we can see that through uncontrolled exposure to such violence the youngsters are loosing their personal values and qualities in the long run.

Our argument is that one of the possibilities for preventing too much exposure to media violence, is media education and family education.

KEY WORDS: adolescents, family role, media, media and family education, violence 